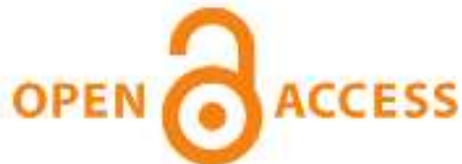

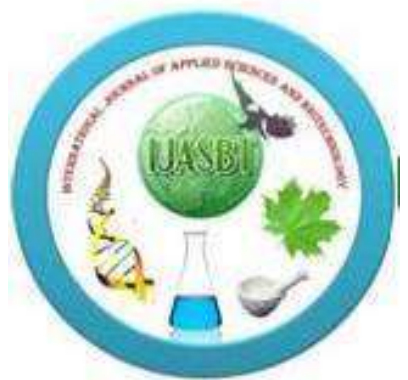 \\ International Journal of Applied Sciences and Biotechnology
}

\author{
A Rapid Publishing Journal
}

ISSN 2091-2609

\section{Indexing and Abstracting}

CrossRef, Google Scholar, Global Impact Factor, Genamics, Index Copernicus, Directory of Open Access Journals, WorldCat, Electronic Journals Library (EZB), Universitätsbibliothek Leipzig, Hamburg University, UTS (University of Technology, Sydney): Library, International Society of Universal Research in Sciences (EyeSource), Journal Seeker, WZB, Socolar, BioRes, Indian Science, Jadoun Science, JourInformatics, Journal Directory, JournalTOCs, Academic Journals Database, Journal Quality Evaluation Report, PDOAJ, Science Central, Journal Impact Factor, NewJour, Open Science Directory, Directory of Research Journals Indexing, Open Access Library, International Impact Factor Services, SciSeek, Cabell's Directories, Scientific Indexing Services, CiteFactor, UniSA Library, InfoBase Index, Infomine, Getinfo, Open Academic Journals Index, HINARI, etc.

\section{CODEN (Chemical Abstract Services, USA): IJASKD}
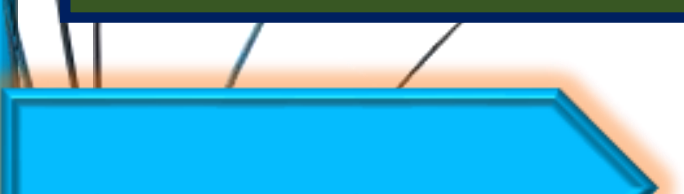

Vol-3(4) December, 2015

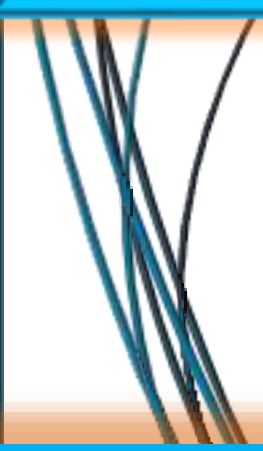

\section{Available online at:}

http://www.ijasbt.org

$\&$

http://www.nepjol.info/index.php/IJASBT/index

Impact factor*: $\mathbf{1 . 4 2 2}$

Scientific Journal Impact factor ${ }^{\#}$ : 3.419

Index Copernicus Value: 6.02

SEM-Biotech

Publishing

*Impact factor is issued by Universal Impact Factor. Kindly note that this is not the IF of Journal Citation Report (JCR). \#Impact factor is issued by SJIF INNO SPACE; **Impact factor is issued by INFOBASE INDEX. 


\title{
SPATIALLY DISTRIBUTION OF QUERCUS SEMECARIFOLIA IN RASUWA DISTRICT USING GIS AND RS
}

\author{
Ila Shrestha \\ Tribhuvan University, Patan Multiple Campus, Lalitpur, Patan Dhoka, Nepal \\ Email: shrestha_ila@yahoo.com
}

\begin{abstract}
The paper is based on the case study of Rasuwa district, is a land of geographical extremes, ranging from $600 \mathrm{~m}$ Betrabati river to $7234 \mathrm{~m}$ Langtang Lirung, the highest point in the northwest. The study was carried out on the detection of Quercus semecarifolia J.E.Smith using Remote-Sensing and Geographic Information System technique. SPOT Image and ERDAS Software have used for the image processing. The program has detected the different types of ecological parameters in tropical to alpine zone and specified the plant species in the study after ground truthing.
\end{abstract}

Keywords: Spatially; Quercus semecarifolia; Rasuwa district; Geographic Information; System, Remote Sensing

\section{Introduction}

Quercus semecarifolia J.E.Smith is a tall tree about $20 \mathrm{~m}$ height called Kharsu oak in English, Kharsu in Nepali, Bhena in Tamang, Dhenu in Rai, Pyena in Gurung, belonging to Fagaceae family. The plants have- leaves stalked, oblong, alternate, , obtuse, entire, glabrous on both sides when old, sparsely stellate hairy above, densely pubescent beneath when young. Male flowers spikes, long, slender, densely pubescent, drooping, yellowish, female spikes short, few- flowered. Fruits are an acorn, solitary, or, in pairs. Plants are propagated by seeds and cuttings. Flowering period is May-June. They are distributed in western, central and east Nepal at $700 \mathrm{~m}-3800 \mathrm{~m}$ on hilly open area. It is also distributed in Afghanistan, Pakistan, Northern India, Southern Tibet, southern China, and Myanmar.

Sap of the plant is drunk as tea. Juice of the bark is applied to relieve muscular pain. Wood is used for building construction purposes and is a good fuel wood. Bark contains tannin. Leaves are lopped for fodder (Manandhar, 2002).

"GIS is a computer-based system that provides four sets of capabilities to handle geo-referenced data: data input, data management, manipulation, and analysis, and data output" (Aronoff, 1989).

Geographic Information Systems are concerned with the digital capture of spatial data and spatially related attributes and their linkage relative to one another. Most importantly, geographic information processing deals with the query, analyses, reporting and output of these data. Remote sensing has always provided a primary source of geographic data to these systems, although not in the digital sense (Archibald, 1987).

\section{Methodology}

The SPOT (Satellite Pour I' Observation de la Terre) satellite data have been used during the research study. It is in the form of false color composite (FCC) having a resolution of $20 \mathrm{~m}$ sq. The SPOT uses spectral bands with the capability to discriminate plants. Satellite has three spectral bands so each pixel of SPOT satellite data consist three-file value. The SPOT uses four bands; among them the panchromatic band has stereo capability. The SPOT satellite has the best resolution amongst the other remote sensing satellites and its products have been selected for this study and collection of ground information. The base map on 1:50,000 scale and 1: 25000 scale sheets have prepared from the survey of the topography of Nepal. Supervise classification have been done in long image process.

\section{Green Band (Band I)}

In the SPOT data of Green Band (Band 1) the minimum data file value is 23 and maximum data file is 72 . The data file values are grouped according to the following spectral ranges 23 to 27 (1); 28 to 32 (2); 33 to 37 (3); 38 to 42 (4); 43 to $47(5) ; 48$ to $52(6) ; 53$ to $57(7) ; 58$ to $62(8) ; 63$ to 67 (9); and 68 to 72 (10).

\section{Red Band (Band 2)}

For the Red Band (Band 2), minimum spectral value is 12 and maximum spectral value is 76 . Pixels were grouped as 
spectral class according to the following spectral range 12 to $16(1) ; 17$ to 21 (2); 22 to 26 (3); 27 to 31 (4); 32 to 36 (5); 37 to 41 (6); 42 to 46 (7); 47 to $51(8) ; 52$ to $56(9) ; 57$ to 61 (10); 62 to $66(11) ; 67$ to $71(12)$; and 72 to $76(13)$.

\section{Near Infrared Band (Band 3)}

For the Near Infrared Band (NIR) Band 3, minimum spectral value is 14 and maximum spectral value is 93 . Pixels were group as following spectral ranges, 14 to 18 (1); 19-23 (2); 24 to 28 (3); 29 to 33 (4); 34 to 38 (5); 39 to 43 (6); 44 to 48 (7); 49 to $53(8) ; 54$ to $58(9) ; 59$ to $63(10) ; 64$ to 68 (11); 69 to 73 (12); 74 to 78 (13); 79 to $83(14) ; 84$ to 88 (15) and 89 to 93 (16).

The supervised classification has used, in this method to create training samples. The Training samples are the sets of pixels that recognized as potential classes. The statistics from the sample pixels has calculated to create the signature of the classes. The signature of the training samples, have derived based on spatially defined and species homogenous sample. The standard deviation of each sample is unique quantitatively and qualitatively for each class. Twenty nine sample plots have been marked in the maps after image processing and identified in the field with the help of Topographic sheets and GPS. In the identified point $50 \mathrm{~m} \mathrm{x}$ $50 \mathrm{~m}$ quadrate have prepared for the study of ecological parameters.
The analysis of the satellite imagery has been carried out using visual image processing techniques by the Mountain Environment and Natural Resources' System (MENRIS) Division of the International Centre for Integrated Mountain Development (ICIMOD), Nepal. Black and white aerial photographs have been used as secondary data. Erdas Imagine 8.3.1 software was applied during the image processing.

\section{Result and Discussions}

The spatially defined and spectrally homogenous field samples are spatial image segment which can identify biological units based on spectral homogeneity of individual spectral bands in the specific digital range and also field survey (Myint, 1996). Similarly, twenty nine points have been marked in the spatially defined and spectrally homogeneous field sample maps (Fig. 1). Identified the accurate field with the help of topography maps, GPS and aerial photographic sheets for the study of ecological parameters. But only, Quercus semecarifolia Sm. have been distributed only in six sample plots, 2, 3, 4, 5, 8, and 24 in Rasuwa District of Nepal. Detailed information of the species has been given in each sample plots.

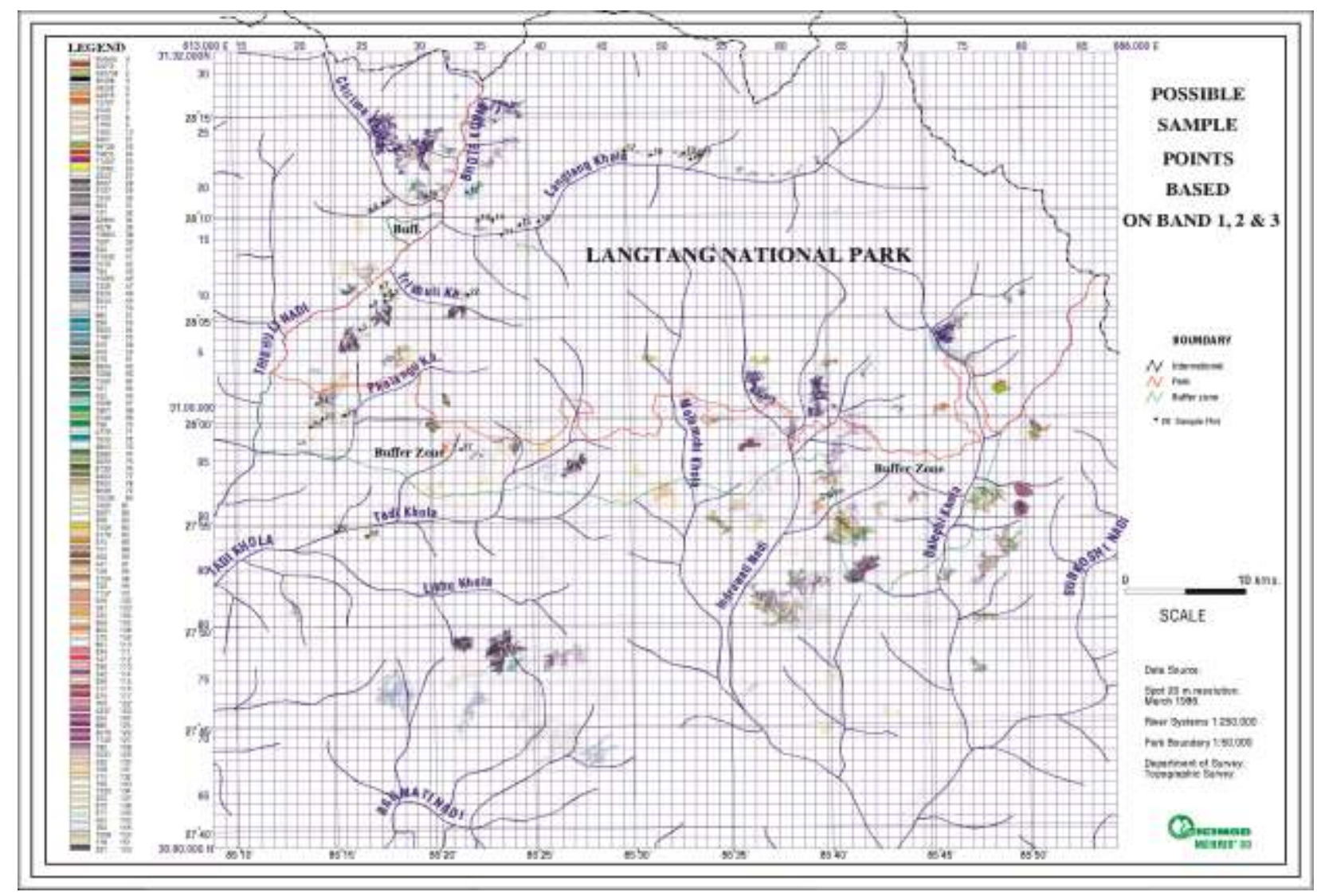

Fig. 1: Map showing distribution of Quercus semecarifolia in Rashuwa district 


\section{Sample Plot No. 2}

The spectral range of 57 to 61 in the Red Band identified Quercus semecarifolia J.E.Smith in this plot lies Dhunche city with an altitude $2320 \mathrm{~m}$ and longitude and latitude of this plot is $85^{\circ} 18.07^{\prime}$ and $28^{\circ} 06.2^{\prime}$ respectively. The associated tree species were Alnus nepalensis D. Don, Benthamidia capitata (Wall.) Hara, Berberis aristata DC., Betula utilis D. Don, Eurya acuminata DC., Lyonia ovalifolia (Wall.) Drude, Alnus nepalensis D. Don, Prunus cerasoides D. Don, Quercus semecarifolia J.E.Smith, Tsuga dumosa (D. Don) Eichler.

\section{Sample Plot No. 3}

The spectral range of 57 to 61 in the Red Band was identified Quercus semecarifolia J.E.Smith in this plot, lies in southern direction of Dhunche bazar with an altitude 1950 m., 85 $17.07^{\prime}$ E longitude and $28^{\circ} 05.88^{\prime} \mathrm{N}$ latitude. About $20 \%$ of the area was covered by Drapanostachyum falcata Nees., and associated with Benthamidia capitata (Wall.)Hara, Berberis aristata DC., Betula alnoides Buch-Ham ex D. Don, Eurya ceracifolia (D. Don) Kobuski,, Lindera pulcherrima (Nees) Benth. ex Hook.f.,, Lyonia ovalifolia (Wall), Drude, Rhododendron arboreum J.E.Smith, Quercus incana Roxb., Quercus lanuginosa D. Don and Tsuga dumosa (D. Don) Eichler.

\section{Sample Plot No. 4}

The spectral range of 38 to 42 in the Green Band was identified Quercus semecarifolia J.E.Smith and lies in the Dhunchebazar at an altitude $2350 \mathrm{~m} ., 85^{\circ} 17.7^{\prime} \mathrm{W}$ longitude and $28^{\circ} 06.20^{\prime} \mathrm{N}$ latitude. Quercus incana Roxb., Lithocarpus grandifoila (D. Don) S.N.Biswas, Eurya acuminata DC., and Benthamidia capitata (Wall.) Hara., were dominant and other associated species were Berberis aristata DC., Betula utilis D. Don, Elaeagnus conferta Roxb., Roxb.,Indigofera dosua BuchHam. ex D. Don, Lindera pulcherrima (Nees) Benth. ex Hook. f., Lyonia ovalifolia (Wall.) Drude, Prunus cerasoides D. Don, Quercus lanuginosa D. Don, Rhododendron arboreum J.E. Smith ,Semecarpus anacardium L.f., Symplocos theaefolia D. Don, Tsuga dumos (D. Don) Eichler, Viburnum coriaceum Blume, and Viburnum mullaha found in this plot.

\section{Sample Plot No. 5}

The spectral range of 29 to 33 in the Near Infra-Red Band, Band 3 was identified as Quercus semicarpifolia J.E. Smith, located in sample plot number 5. This plot is situated at the Boke Jhunda called Yanglaguli forest, lies in west facing plot at an altitude $2620 \mathrm{~m}$. and the longitude and latitude of this plot is $85^{\circ} 16.38^{\prime}$ and $28^{\circ} 04.54^{\prime}$ respectively. The total number of tree species found in this plot is nine. The Ilex dipyrena Wall was a dominant tree associates with Lindera pulcherrima (Nees) Benth. ex Hook. f. Other associated species were Abies spectabilies (D. Don) Mirbel, Acer campbellii Hook. f. et Thoms. ex Hiern, Eurya accuminata DC., Pieris Formosa
(Wall.) D. Don, Rhododendron campanulatum D. Don \& Tsuga dumosa (D. Don) Eichler.

\section{Sample Plot No. 8}

The spectral range from 22 to 26 in the Red Band 2, was identified as the Quercus semecarifolia J.E. Smith, forest in sample Plot number 8. It is located in Tatopani (hot spring area) at an altitude $2770 \mathrm{~m}$ with the longitude and latitude of this plot is $85^{\circ} 18.28^{\prime}$ and $28^{\circ} 13.33^{\prime}$ respectively. The total number of tree species found in this plot is seven. They are Acer campbellii Hook.f.et Thoms. ex Hiern, Eurya acuminate DC., Berberis aristata DC., Ilex dipyrena Wall, Lindera pulcherrima (Nees) Benth. ex Hook. f., and Lyonia ovalifolia (Wall.) Drude,

\section{Sample Plot No. 24}

The spectral range of 59 to 63 in the Infrared Band was identified as Quercus semecarifolia J.E.Smith in Lokyule at an altitude 2400 m., 85 $14.12^{\prime} \mathrm{E}$ and $28^{\circ} 00.83^{\prime} \mathrm{N}$. Lyonia ovalifolia (Wall) Drude was a dominant species associated with Abies spectabilis (D. Don) Spach, Berberis aristata DC. ,Eurya acuminata DC., Ilex dipyrena Wall., Lindera pulcherrima (Nees) Benth. ex Hook. f., Pieris formosa (Wall) D. Don, Pinus roxburghii Sargent, Pyrus pashia Buch-Ham. ex D. Don, Quercus incana Roxb., Quercus lanuginosa D. Don, Rhododendron arboreum Sm., Semecarpus anacardium L.f., Tsuga dumosa (D. Don) Eichler and Viburnum coriaceum Blume.

\section{Acknowledgements}

I am very grateful to Patan Multiple Campus, Tribhuvan University for granting me study leave. I would also like to thank the Department of National Parks and Wildlife Conservation for giving permission to carry out the field study in Langtang National Park. I also acknowledge International Centre for Integrated Mountain Development (ICIMOD), MENRIS Division for providing every possible technical and financial support on Remote Sensing and Geographic Information System.

\section{References}

Archibald PD (1987) GIS and Remote Sensing Data Integration, Geocarto International, Vol 2, pp. 67-73.

Aronoff S (1989) Geographic Information System: A Management Perspective. Ottawa: WDL Publishers.

Manandhar NP (2002) Plants and People of Nepal. Timber press, Inc. Portland, Oregon, USA.

Myint M (1996) The Use of remote sensing data for inventory on biodiversity of National Parks: A case study of the Alaungdaw Kathapa National Park in Myanmar"; A Ph.D. dissertation report, Asian Institute of Technology, School of Environment, Resource and development, Bangkok, Thailand.

Press JR, Shrestha KK and Sutton DA (2000) An Annotated Checklist of Flowering Plants of Nepal. British Museum (Natural History) London and Central Department of Botany, T. U. Kirtipur, Nepal. 